\title{
Multidimensional Poverty: An Exploratory Study in Purulia District, West Bengal
}

\author{
Supravat Bagli ${ }^{* 1}$ and Goutam Tewari ${ }^{2}$ \\ ${ }^{1}$ Associate Professor of Economics, Presidency University, Kolkata, West Bengal, India \\ ${ }^{2}$ Department of Economics, Sidho-Kanho-Birsha University, Ranchi Road, Purulia, West Bengal, India \\ "Corresponding author: supravat.bagli@gmail.com (ORCID ID: 0000-0002-1845-4591)
}

Received: 11-03-2019

Revised: $13-06-2019$

Accepted: 09-08-2019

\begin{abstract}
This paper explores the incidence and extent of multidimensional poverty for the households in Purulia district, the western most backward district of West Bengal in India. In context of Purulia district the decompositions of multidimensional poverty index (MPI) across the social castes and across the indicators have also been explained. MPI and its decomposition across the sub-groups have been computed using the methodology developed by Alkire and Foster (2007) and Alkire et al. (2011). This study covers twelve non income indicators under three dimensions education, health and living conditions. Collecting a set of primary data from 698 households in Purulia district during 2018, this study reveals that the incidence of multidimensional poverty in the district of Purulia is higher than that in national level. But the breadth of poverty is almost equal to that in India as a whole. In respect of poverty there is wide variation across the social castes. Among the indicators, use of dirty cooking fuel, not having improved sanitation have highest contribution to the district MPI.

Highlights

(0 This paper explores the incidence of multidimensional poverty for the households in Purulia district which is double in figure compared to that in India as a whole. Deprivation in access to improved sanitation is identified as the crucial indicator contributing highest in MPI of Purulia district.
\end{abstract}

Keywords: Decomposition of multidimensional poverty, incidence of multi-dimensional poverty, Multidimensional Poverty Index, Purulia District

In recent years the idea of multidimensional poverty has received a great attention of the researchers and policy makers across the globe. The Senian explanation of poverty, participatory approach to study poverty, Millennium Development Goals, Sustainable Development Goals all ensure the multidimensional nature of poverty. Although, the concept of multidimensional poverty or achievement have been recognised and empirically studied using community level data since late 1980s, it was not applicable to assess the incidence and intensity of multidimensional poverty at the individual/ household level which can also be aggregated at the community level. Secondly, majority of the measures of multidimensional poverty are not simple and don't follow the properties of a standard income poverty measure. Against this backdrop Alkire and Foster (2007) have developed the methodology (hereafter AF methodology) to measure the incidence, intensity and severity of multidimensional poverty at the individual/household level which can be aggregated at the community level. The advantages of these measures are; it can be applied for quantitative and qualitative data and follow the important properties of the standard measures of income poverty like decomposability across the subgroups, decomposability across the indicators and dimensions. As the idea of multidimensional poverty index (MPI) is a non-income measure, it can avoid the errors in the measurement of 
$\underset{\text { AESRA }}{\sqrt{\nu}}$ Bagli and Tewari

income. This paper has been designed to study the incidence, intensity and extent of multidimensional poverty at the household level and estimate the multidimensional poverty at the community level in the district of Purulia. This district was a part of the then state of Bihar at the time of the independence of India. It was included in the state of West Bengal on $1^{\text {st }}$ November, 1956 after a long movement for Bengali Language. The district is situated in the western most part of the state of West Bengal in India. Purulia district is relatively backward among the districts in West Bengal with respect to literacy, health care facility, safe drinking water facility, sanitation, housing condition, urbanisation and communication. Moreover, the district is the third income poorest district among the districts in West Bengal. Thirty-eight per cent of the population in this district belongs scheduled castes and scheduled tribes (Census Report, 2011). Compared to rest part of West Bengal and India the situation of Purulia district did not change radically during the last 70 years. Although, the governments and NGOs have been working since the inception of the district in West Bengal and achieved in a position. More can still be done in the dimensions of multidimensional poverty in Purulia district. But the budget should be allotted in apriority basis and the policy makers should have the priority list of area where the government emphasises for alleviating multidimensional poverty. In this perspective, the availability of the current estimate of multidimensional poverty and the contribution of the individual indicators are imperative. This paper does this task with the help of very recent collected household level data from Purulia district.

\section{Literature Review and Objectives}

There are many empirical studies on multidimensional poverty considering micro level data across the world. We have reviewed some selected studies in India and abroad related to this study. Money metric measure is not sufficient to reveal the poverty in multiple dimensions for a household or a country. It is supported by the study in India of RuggeriLaderchi et al. (2003) reporting 43 percent of children and more than $50 \%$ of adult are poor in respect of health and education indicator, while they are nonpoor in respect of money-metric measure. Alkire and Santos, (2010), have reported that most of the world's multidimensional poor live in south Asia and Sub-Saharan Africa. They have calculated that 55.4 per cent of the population of India is multidimensionally poor. The extent of multidimensional poverty among the Indian states is highest in Bihar followed by Jharkhand, Uttar Pradesh, and Madhya Pradesh. It shows that the value of MPI of West Bengal was 0.32 in 2008-09. Ningaye et al. (2011) have studies the multidimensional poverty of the households in Cameroon and compared it with monetary poverty. Exploring five dimensions of multi-poverty viz. monetary poverty, existence poverty, human poverty, infrastructural poverty, and financial poverty, they have found that residential region, age of the households head, major household occupation, type of household, agro-ecological zone are important determinants of the incidence of multidimensional poverty of the households.

Haveman and Dhongde (2014) have estimated multidimensional poverty index (US-MPI) applying the AF methodology for U.S.A using data from the American Community Survey (ACS), 2011. They find that 13.7 percent of the entire sample had income less than poverty line income but among the multidimensional poor 12.6 percent were income poor. It is revealed that the contribution of income poverty in MPI is calculated to 18.2 percent. Zahra and Zafar (2015) have tried to find out the extent of multidimensional poverty and its determinants among Christian community living in the slums of the Lahore city of Pakistan. Based on the data of 1380 individuals belonging to this minority group, the study shows more than half of population is multidimensional poor. The constraints in achieving a good standard of living can create sense of deprivation among this marginal community, these causes a deprivation of education, employment and health among these individual. This community is caught in the vicious circle of poverty, and the poor socio-economic infrastructure does not allow them to be out of poverty. Almost one third of population is deepens in poverty in two or more than two dimensions and one fourth of the population live with the severity of multidimensional poverty.

Alkire and Robles (2017) have computed the global multidimensional poverty index covering $76 \%$ of the world population residing in 103 countries. In respect of the MPI this study has identified South Sudan as poorest country in the World followed 
by Niger, Ethiopia, Chad, Burkina Faso, Somalia. Kazakhstan is the least poor country preceded by Serbia, Montenegro Armenia. India has got $37^{\text {th }}$ rank among the 103 countries when countries are arranged in poorest to non-poor order. The position of India worse than Bangladesh, even than Nepal, Bhutan. However, there is wide dispersion inside the regions.

De and Datta (2014) have estimated MPI applying AF methodology for the Toto community in Jalpaiguri district in West Bengal based on a sample of size 49 households. They have reported that more than 80 percent of the sample population are multidimensionally poor. The MPI is 0.57 for the sample population. They conclude that the multidimensional poverty of totos in Jalpaiguri district is similar to that of Ethiopia. Vijaya, et al. (2014) construct an individual level multidimensional poverty measure for Karnataka, India. They have calculated gender disaggregated KHAS-MPI for 10 different poverty cut offs ranging from 10 per cent to 100 per cent deprivation, to see if their result of higher poverty rates among women holds across different poverty lines. Poverty head count is greater for women across the different cut-offs KHAS-MPI for women dominates KHAS-MPI for men across the different poverty cut-offs. Poverty among women is higher than men irrespective of the deprivation poverty cut-off chosen to define the poor. Based on a set of primary data Bagli (2015) has also reported the MPI for two CD blocks, Kotulpur and Chhatna into the district of Bankura in West Bengal. He has shown that per capita household income, landholding, major occupations and castes as significant determinants of multidimensional poverty for the households. The probability to be an extreme multidimensional poor is lower for a tribal household compared to a scheduled castes household.

However, in contrast to scheduled castes, scheduled tribes are more likely to be marginal poor and vulnerable. Dehury and Mohanty (2015) have estimated the regional level multidimensional poverty in India using the Indian Human Development Survey (IHDS), 2004-05 data. Results indicate that about half of India's populations are multidimensional poor with large regional variations. They have found that the states of Uttar Pradesh, Bihar, Chhattisgarh, Jharkhand, Madhya
Pradesh, Odisha and West Bengal where share of poverty is higher than the share population. The decomposition of MPI indicates that economic dimension alone accounts for about one-third of multidimensional poverty in most of the regions. Using a set of household level primary data from West Bengal Roy, et al. (2018) have estimated the incidence, depth and severity of multidimensional poverty for the rural households. They also decompose the inequality of deprivation scores between and within the different socio-economic, religious and ethnic groups. They have found that health dimension has highest contribution among the dimensions on multidimensional poverty and public infrastructure plays an important role to determine the incidence of multidimensional poverty. Thus, the study of the nature of multidimensional poverty of the households from the districts in India, particularly, in southern part of West Bengal is not common. With this end in view, this study has been organised with the objectives as follows:

- First, we study the incidence and the intensity of multidimensional poverty for the households in Purulia district.

- Second, the decomposition of multidimensional poverty index across the social castes and across the indicators have been explained.

\section{Methodology and Data}

This section deals with the methodology for measuring household level multidimensional poverty and a non-income poverty measure in the district of Purulia. This study follows the AF methodology for quantifying the incidence and intensity of multidimensional poverty for Purulia district considering a set of relevant indicators as mentioned in table 1 .

We have gathered the required information for the indicators asking the respondents and from our personal observations during the course of field survey. Among the indicators the measure of nutritional status of the household members is difficult one. Usually, the nutritional status is measured by Body Mass Index (BMI) for adults and weight for age for children. It is difficult to follow these accurate measures for each household member due to our time and technical constraints. Most of the cases we have recorded the self-reported 
health status. Often, we measure it by personal observations keeping the measures of BMI and weight for age of children in mind.

In the box the indicators are stated in view of the deprivation. If the statement is true we say that there is deprivation in the household in respect of the particular indicator. We assign value ' 1 ' for deprivation of the household in each indicator $\left(D_{i}\right)$ and ' 0 ' otherwise. Following UNDP, equal weight has been attached for each dimension and each indicator within a dimension has received equal weight. The intensity of multidimensional deprivation of the households is measured by the formula,

$$
W D S=\sum_{i=1}^{12} w_{i} D_{i}
$$

where $w_{i}$ denotes the relative weight attached with $i^{\text {th }}$ indicator such Note that WDS lies in between 0 and 1 such that as deprivation increases the value of WDS increases and vice-versa. In order to identify the multidimensional poor we now have to choose a cut-off value for the weighted score. According to UNDP a household (or all members of the household) is said to be multi-dimensionally poor if the sum of weighted deprivation score (WDS) for a household is $1 / 3$ or more. This is the second cut off $\left(k_{2}\right)$ in the measure of the intensity of multidimensional poverty at the household level. There is no unanimity among the economist regarding the cut off value. Therefore, considering different values of $\mathrm{k}_{2}$ we assess the robustness of the measure in the context of the households in Purulia district. The multi-dimensionally poverty head count ratio $(\mathrm{H})$ is therefore,

$$
H=q / N
$$

where, $q$ stands for the number of multidimensionally poor households and $N$ is the total number of sample households. Head count ratio measures the incidence of poverty of the households. The average intensity of multidimensional poverty $(\mathrm{A})$ reflects the proportion of the weighted component indicators, in which, on average, poor people are deprived of. This measure is called the breadth of multidimensional poverty. Technically,

$$
A=\sum_{1}^{q} \frac{W D S}{q}
$$

where, WDS denotes the total weighted score of deprivations for the poor people in respect of all the dimensions of deprivation. Finally, the multi-dimensional poverty index is obtained by multiplying the multi-dimensionally poverty head count ratio $(\mathrm{H})$ with the average intensity of multidimensional poverty (A). Therefore,

$$
M P I=H \times A
$$

According to OPHI group of researchers the measure is called adjusted headcount, $M_{0}$ for multidimensional poverty. MPI has some nice properties like decomposability, monotonicity, applicable for categorical, ordinal or cardinal indicators.

In order to decompose the MPI across the mutually exclusive and exhaustive strata of households in respects of social castes we use the following formula,

$$
\begin{aligned}
M P I_{D i s t}= & \frac{N 1}{N} M P I_{G e n}+\frac{N 2}{N} M P I_{O B C}+\frac{N 3}{N} M P I_{S C}+ \\
& \frac{N 4}{N} M P I_{S T}
\end{aligned}
$$

where, ' $N$ ' stands for total number of households of them $\mathrm{N} 1$ are belonging to general caste, $\mathrm{N} 2$ belongs to OBC, N3 belongs to SC community and N4 are ST households. The percentage contribution of each community to overall poverty can be measured applying the following formula developed by Alkire, et al. (2011). For example, contribution of General Caste households to,

$$
\mathrm{MPI}=\frac{\frac{N 1}{N} M P I_{G e n}}{M P I_{\text {Dist }}} * 100
$$

If the contribution of a subgroup to the overall poverty is greater than its population share, we conclude that poverty disproportionately distributed across the study strata.

In order to decompose the MPI by indicators, first we compute the censored head count ratio for each indicator. The censored head count ratio for an indicator is the ratio of the number of multidimensional poor who are deprived of the particular indicator to total sample size The censored head count ratio $(\mathrm{CH})$ for a particular indicator is as follows, 


$$
C H_{i}=\frac{1}{N} \sum_{j}^{q} D_{i j}
$$

Such that, $D_{i j}$ takes value ' 1 ' when the $j^{\text {th }}$ multidimensionally poor household is deprived in $i^{\text {th }}$ indicator and ' 0 ' otherwise. Then, the decomposition formula of MPI across the indicators can be written as follows,

$$
M P I_{D i s t}=\sum_{i=1}^{12} w_{i} C H_{i}
$$

Here $w_{i}$ denotes the relative weight attached with $i^{\text {th }}$ indicator. The percentage contribution of each indicator to overall poverty can be measured with the following formula,

Contribution of $i^{\text {th }}$ indicator to MPI $=\frac{w_{i} C H_{i}}{M P I_{D i s t}} * 100$

Whenever the contribution of a particular indicator to the overall poverty is widely greater than its relative weight, the deprivation is relatively high in this indicator. In other words, the multidimensionally poor households are more deprived in this indicator than in others.

The estimation of multidimensional poverty is based on a set of household level data collected from 698 households during May-August, 2018 in Purulia district covering four community development blocks and three municipalities. Data have been collected following multi-stage sampling technique. In the first step purposively selected four blocks Jhalda-1, Purulia-1, Raghunathpur-1 and Para and three municipalities. Two Gram Panchayats have been selected randomly from each Block in stage two. In stage three we have randomly selected four residential villages from each selected gram panchayat and one ward from each municipality. Finally, data have been collected from randomly selected 698 households considering more or less 20 households from each selected village and municipality depending on its demographic features.

\section{Empirical Findings}

The results of the estimates of incidence, intensity, and extent of multidimensional poverty have been discussed in this section. Table 1 and 2 depict the description of socio-economic and demographic variables of the sample households. It shows that average monthly per capita income of the sample households is rupees 1648 which ranges from ₹ 334 to ₹ 25000 . However, majority of the sample households have per capita monthly income ₹ 1000 . In an average monthly per capita expenditure is less than the average income. However, inequality in expenditure is much higher than that of income. Average family size of the sample households is 4 . It is a good indicator that average sex ratio of the sample households is 1103 . The figure of median of sex ratio tells us majority of the households are comprised of equal number of males and females. In respect of per capita landholding sample households are poor in average. But there is huge inequality among the sample households in terms of per capita land holding.

\section{Indicators of Multidimensional Poverty in Purulia

\begin{tabular}{|c|c|c|}
\hline Dimension & $\begin{array}{l}\text { Deprivation criteria for the Selected } \\
\text { Indicators }\left(D_{i}\right)\end{array}$ & $\begin{array}{l}\text { Weight } \\
\left(w_{\mathrm{i}}\right)\end{array}$ \\
\hline \multirow{4}{*}{ Health } & $\begin{array}{l}\text { 1. No access to formal health clinic } \\
\text { during illness }\end{array}$ & $1 / 12$ \\
\hline & $\begin{array}{l}\text { 2. At least one member suffers from } \\
\text { malnutrition }\end{array}$ & $1 / 12$ \\
\hline & $\begin{array}{l}\text { 3. One or more members aged below } \\
40 \text { years died during last five years }\end{array}$ & $1 / 12$ \\
\hline & $\begin{array}{l}\text { 4. At least one member suffers from } \\
\text { hunger during last year }\end{array}$ & $1 / 12$ \\
\hline \multirow{3}{*}{ Education } & $\begin{array}{l}\text { 1. No one has completed five years of } \\
\text { schooling }\end{array}$ & $1 / 9$ \\
\hline & $\begin{array}{l}\text { 2. At least one school-age child not } \\
\text { enrolled in school }\end{array}$ & $1 / 9$ \\
\hline & 3. No one has financial literacy & $1 / 9$ \\
\hline \multirow{5}{*}{$\begin{array}{l}\text { Living } \\
\text { Condition }\end{array}$} & $\begin{array}{l}\text { 1. No electric connection at the } \\
\text { residence }\end{array}$ & $1 / 15$ \\
\hline & 2. No access to safe drinking water & $1 / 15$ \\
\hline & 3. No access to improved sanitation & $1 / 15$ \\
\hline & $\begin{array}{l}\text { 4. Cooks using dung, wood or } \\
\text { charcoal, crop residue as fuel. }\end{array}$ & $1 / 15$ \\
\hline & $\begin{array}{l}\text { 5. Household has no car and owns at } \\
\text { most one of: bicycle, motorcycle, } \\
\text { refrigerator, cell phone or } \\
\text { television }\end{array}$ & $1 / 15$ \\
\hline
\end{tabular} District}

Source: Authors' justification in the context of Purulia District.

Table 2 shows that average highest education level of male members in household is 6 years plus. In majority of the households, highest education 
Table 1: Socio-Economic-Demographic Description of the Sample Households (N=698)

\begin{tabular}{ccccccc}
\hline Statistic & $\begin{array}{c}\text { Monthly } \\
\text { Per capita } \\
\text { Household } \\
\text { Income (₹) }\end{array}$ & $\begin{array}{c}\text { Per capita Monthly } \\
\text { Household } \\
\text { expenditure (₹) }\end{array}$ & $\begin{array}{c}\text { Family Size } \\
\text { (Number) }\end{array}$ & $\begin{array}{c}\text { Sex Ratio Per } \\
\mathbf{1 0 0 0} \\
\text { (N=651) }\end{array}$ & $\begin{array}{c}\text { Dependency } \\
\text { Ratio } \\
\text { (\%) }\end{array}$ & $\begin{array}{c}\text { Per Capita Land } \\
\text { holding (Bigha) }\end{array}$ \\
\hline Mean & 1647.79 & 1323.69 & 4.10 & 1103 & 60.59 & 0.37 \\
Median & 1000.00 & 730.00 & 4.00 & 1000 & 66.67 & 0.08 \\
Maximum & 25000.00 & 47580.00 & 11.00 & 5000 & 100.00 & 17.50 \\
Minimum & 333.33 & 100.00 & 1.00 & 250 & 0.00 & 0.00 \\
Std. Dev. & 2455.66 & 2953.49 & 1.60 & 867.27 & 21.34 & 0.89 \\
CV & 1.49 & 2.23 & 39.02 & 78.62 & 35.22 & 240.54 \\
Skewness & 4.48 & 11.71 & 0.45 & 2.18 & -1.41 & 12.05 \\
Kurtosis & 26.61 & 175.06 & 3.95 & 5.50 & 4.59 & 209.43 \\
\hline
\end{tabular}

Source: Authors' computation based on household survey 2018.

Table 2: Socio-Economic-Demographic Description of the Sample Households (N=698)

\begin{tabular}{ccccccc}
\hline Statistic & $\begin{array}{c}\text { Highest } \\
\text { education } \\
\text { among the } \\
\text { males (Year) }\end{array}$ & $\begin{array}{c}\text { Highest } \\
\text { education among } \\
\text { the females } \\
\text { (Year) }\end{array}$ & $\begin{array}{c}\text { Members } \\
\text { attended } \\
\text { 5years of } \\
\text { schooling }\end{array}$ & $\begin{array}{c}\text { Education of the } \\
\text { Household Head } \\
\text { (Year) }\end{array}$ & $\begin{array}{c}\text { Age of the } \\
\text { Household } \\
\text { Head(year) }\end{array}$ & $\begin{array}{c}\text { Number of } \\
\text { Bedrooms in the } \\
\text { Household }\end{array}$ \\
\hline Mean & 6.85 & 4.92 & 1.77 & 3.68 & 47.07 & 1.49 \\
Median & 8.00 & 4.00 & 2.00 & 0.00 & 47.00 & 1.00 \\
Maximum & 21.00 & 21.00 & 10.00 & 21.00 & 85.00 & 5.00 \\
Minimum & 0.00 & 0.00 & 0.00 & 0.00 & 1.00 & 0.00 \\
Std. Dev. & 5.12 & 5.06 & 1.54 & 5.05 & 13.46 & 0.75 \\
C. V & 74.74 & 102.84 & 87.00 & 137.22 & 28.59 & 50.33 \\
Skewness & 0.03 & 0.53 & 0.83 & 2.11 & 0.16 & 1.71 \\
Kurtosis & 1.92 & 2.07 & 4.32 & 15.24 & 2.52 & 6.30 \\
\hline
\end{tabular}

Source: Authors' computation based on household survey 2018.

among male members is eighth standard while highest education among female members is only fourth standard. Thus, there is huge education gap among the male and female members within the households. If we compare the inequality in highest education of male and female within the households we see that inequality in highest education of female members is 1.5 time higher than that of male members. However, on average two members of aged 10 and above years in the sample households have at least primary level education. We see that average education level of the household heads is lower than the average highest education of the male and female members in the sample households. Majority of the households are illiterate. In the sample almost all the households are maleheaded with average age of 47 years. Majority of the household resides in one bedroom residential house.
Table 3 displays the percentage distribution of the categorical variables indicating the socio-economicdemographic treats of the sample households. Three fourth of the sample households are of nuclear type. We find that 61 per cent of the sample households earn their livelihood form daily wage engaging in informal activities. More than half of the sample households are landless. Among the landed households (332) 46 per cent are engaged in cultivation of paddy, potato, and vegetables. Ten per cent of the sample households mainly engaged themselves in self-employed activities like grocery, agri-business, informal services and manufacturing. Only 6 per cent of the sample households mainly earn from formal services in government and nongovernment institutions. In respect of social castes $35 \%(10 \%)$ are belonging to general castes (OBC). We have 33 per cent of the sample households scheduled castes while 21 per cent scheduled tribes. 
Table 3: Socio-economic and Demographic Attributes of the Sample Households (N=698)

\begin{tabular}{lcc}
\hline Attributes & Number & Percentage \\
\hline Nuclear Households & 523 & 74.93 \\
Cultivation as Main Occupation & 156 & 22.35 \\
Self-employment as Main Occupation & 71 & 10.17 \\
Service as Main Occupation & 45 & 6.45 \\
Wage labour as Main Occupation & 426 & 61.03 \\
Agricultural Landless households & 366 & 52.43 \\
Households belonging to General Castes & 242 & 34.67 \\
Households belonging to OBC & 73 & 10.45 \\
Households belonging to Scheduled Castes & 235 & 33.66 \\
Households belonging to Scheduled Tribe & 148 & 21.20 \\
Village as Residential Region of the Households & 624 & 89.40 \\
Households holding BPL Card & 551 & 78.94 \\
At least one adult is seeking for job & 357 & 51.15 \\
At least one child in the households work for earning & 58 & 9.89 \\
At least one child in the households not enrolled in School & 58 & 8.31 \\
At least one child died last five year before attending 14 years of age & 2 & 0.29 \\
Children took birth at home in the last year & 12 & 1.72 \\
Residential House with Concrete Wall & 156 & 22.35 \\
Residential House with Concrete Roof & 106 & 15.19 \\
Participation in Self-Help Group Centric Microfinance Program & 91 & 13.03 \\
Participation in MGNREG & 257 & 36.81 \\
Households received any kind of social Security Benefit & 90 & 12.89 \\
At least one member has leadership position in any one organisation & 126 & 18.05 \\
\hline
\end{tabular}

Source: Authors' computation based on household survey 2018.

As Purulia is a rural and remote district, $89 \%$ of the surveyed households reside at rural areas. It is not surprising that 79 per cent of the sample households have BPL card. Half of the sample households has reported that at least one adult is seeking for job. Thus, statistics of dependency ratio, engagement in service and self-employment and data of job seeking indicates unemployment as a serious problem in the district under study. Ten per cent of the households send their children for earning and 8 per cent of the households don't send their children to school. Incidence of child labour and non-enrollment of children in school is thus not an insignificant problem in Purulia district. It is observed that only $22 \%$ of the sample households has concrete wall and $15 \%$ has concrete roof of their residential unit. From 13\% (37\%) of the sample households at least one female (adult) has participated in Self-Help group based microfinance (MGNREGS) program. In the last year $13 \%$ of the sample households has reported that at least one member has received social security benefit like old age pension, health insurance, Janani Surakha Janani etc. Moreover, 29\% of the households has benefited from government provision of physical instrument like subsided LPG connection, housing materials, cycles etc. In $18 \%$ of the sample households at least one member acts as leader of any kind of social or political organization.

Table 4 shows the statistics of the selected indicators. It is reported that $15 \%$ of the sample households don't have access to formal clinic during illness. They usually use own made herbal indigenous medicine, medicine from informal practitioners, Ojhas, or depends on Gods. In one third of the households at least one member suffers from malnutrition. 3.3 per cent of the households has faced the incidence of unexpected mortality (at least one member died before attending 40 years). It is not surprising that hunger is a significant economic problem to the households in Purulia district. $27 \%$ of the households has reported that no one has passed primary level education. At least one 
Table 4: Description of the Selected Indicators of Multidimensional Poverty (N=698)

\begin{tabular}{|c|c|c|c|}
\hline 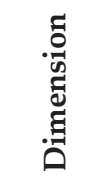 & Deprivation criteria $\left(D_{i}\right)$ & $\begin{array}{c}\text { Number of } \\
\text { Deprived } \\
\text { Households }\end{array}$ & $\begin{array}{l}\text { Percentage in } \\
\text { total number of } \\
\text { households }\end{array}$ \\
\hline \multirow{4}{*}{$\begin{array}{l}\text { 志 } \\
\text { 疍 }\end{array}$} & No access to formal health clinic during illness & 103 & 14.76 \\
\hline & At least one member suffers from malnutrition & 240 & 34.38 \\
\hline & One or more members aged below 40 years died during last five years & 23 & 3.30 \\
\hline & At least one member suffers from hunger during last year & 293 & 41.98 \\
\hline \multirow{3}{*}{ 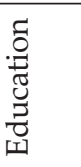 } & No one has completed five years of schooling & 189 & 27.08 \\
\hline & At least one school-age child not enrolled in school & 68 & 9.74 \\
\hline & No one has financial literacy & 218 & 31.23 \\
\hline \multirow{5}{*}{ : } & No electric connection at the residence & 212 & 30.37 \\
\hline & No access to safe drinking water & 186 & 26.65 \\
\hline & No access to improved sanitation & 548 & 78.65 \\
\hline & Use of cooking fuel like dung, wood or charcoal, crop residue. & 531 & 76.07 \\
\hline & Household owns at most one of census asset & 143 & 20.49 \\
\hline
\end{tabular}

Source: Authors' computation based on household survey 2018.

child (up to 14 years) of 10\% sample households are not enrolled in school. Further, commendable extension of banking service across the all corners of India fails to bring 31\% of the sample households under the purview of banking services. So, 31\% of the households are financial illiterate. It is fact that $30 \%$ of the sample households has no electric connection for lighting. More than one fourth of the surveyed households collect drinking water from unsafe sources. Majority of these households drink water with iron contamination and faced shortage of drinking water during every summer. Our survey has explored that $78 \%$ of the sample households do not have access to improved sanitation and only one fourth of the sample households have access to modern fuel and energy for cooking. We find that $80 \%$ of the sample households are not asset poor. A few households have car, refrigerator and landline telephone connection along with other household amenities. Ownership of bicycle, mobile, motorcycle and television are very common in the area under study.

Table 5 provides the incidence, intensity and index of multidimensional poverty for the district of Purulia in West Bengal. We have found that in this district $49 \%$ households are multi-dimensionally poor while this percentage for India is $27 \%$ in 2018 estimated by UNDP, 2018. This result explores the incidence of multidimensional poverty Purulia district as similar to Yemen in $2013(47.8 \%)$, a country at the southern edge of the Arabian Peninsula in Western Asia, but it is poorer than Bangladesh (41.7\%) in 2014 and Nepal in 2016 (HDI, 2018). The value of intensity of multidimensional poverty of the poor for Purulia district 0.44 which is very close to the estimates of UNDP 2018 for India. Finally, the estimated multidimensional poverty index for Purulia district is 0.21 which is nearly double of the value for India in 2018 (0.121). Our estimated MPI for Purulia district is almost equal to the MPI in 2016 of Timor-Leste, a Southeast Asian country occupying half the island of Timor. The figure of MPI of Purulia district is mildly better than that of Pakisthan (0.228) in 2012-13 and mildly worse than that of Bangladesh (0.194) in 2014 (UNDP Human Development Report, 2018). Therefore, the incidence of multidimensional poverty in the district Purulia is significantly higher than that in India as a whole. However, average deprivation of the poor for Purulia district and India as a whole are almost equal in 2018. Among the multi-dimensionally poor, $33 \%$ are general castes households, $7 \%$ are $\mathrm{OBC}$, $36 \%$ are belonging to scheduled castes and $24 \%$ are scheduled tribes. It is seen that incidence and intensity of multidimensional poverty is highest among the scheduled tribes among the social castes. In all respect households belonging to OBCs are least deprived compared to the deprivation of other social 
Table 5: Caste-Wise Decomposition of Multidimensional Poverty in Purulia District

\begin{tabular}{lccccc}
\hline \multicolumn{1}{c}{ Measures } & $\begin{array}{c}\text { Total Sample } \\
\text { households }\end{array}$ & $\begin{array}{c}\text { General Caste } \\
\text { households }\end{array}$ & $\begin{array}{c}\text { OBC } \\
\text { households }\end{array}$ & $\begin{array}{c}\text { Scheduled Caste } \\
\text { households }\end{array}$ & $\begin{array}{c}\text { Scheduled Tribe } \\
\text { households }\end{array}$ \\
\hline $\begin{array}{l}\text { Number of observations } \\
\text { Number of Multi-dimensionally }\end{array}$ & $698(100 \%)$ & $244(35 \%)$ & $73(10 \%)$ & $233(33 \%)$ & $148(22 \%)$ \\
$\begin{array}{l}\text { Poor } \\
\text { Incidence of Multidimensional }\end{array}$ & $343(100 \%)$ & $115(33.5 \%)$ & $24(6.9 \%)$ & $123(35.86 \%)$ & $81(23.61 \%)$ \\
$\begin{array}{l}\text { Poverty(H) } \\
\text { Intensity of Multidimensional }\end{array}$ & 0.491 & 0.471 & 0.328 & 0.527 & 0.544 \\
$\begin{array}{l}\text { Poverty (A) } \\
\text { Multidimensional Poverty Index }\end{array}$ & 0.218 & 0.435 & 0.434 & 0.452 & 0.456 \\
$\begin{array}{l}\text { (MPI) } \\
\text { Contribution of the Castes to }\end{array}$ & 100 & 0.203 & 0.142 & 0.238 & 0.248 \\
MPI (\%) & 32.57 & 6.82 & 36.02 & 25.02 \\
\hline
\end{tabular}

Source: Authors' computation based on household survey 2018.

Table 6: Indicator-Wise Decomposition of Multidimensional Poverty in Purulia District

\begin{tabular}{|c|c|c|c|}
\hline 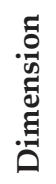 & Deprivation criteria for the Selected Indicators $\left(D_{i}\right)$ & $\begin{array}{l}\text { Censored Head-count } \\
\text { Ratio }\end{array}$ & $\begin{array}{c}\text { Contribution o } \\
\text { the Indicator to } \\
\text { MPI }\end{array}$ \\
\hline \multirow{5}{*}{$\begin{array}{l}\frac{5}{ \pm} \\
\stackrel{\Xi}{\overparen{I}}\end{array}$} & No access to formal health clinic during illness & 0.113 & 0.043 \\
\hline & At least one member suffers from malnutrition & 0.239 & 0.091 \\
\hline & $\begin{array}{l}\text { One or more members aged below } 40 \text { years died during last five } \\
\text { years }\end{array}$ & 0.026 & 0.010 \\
\hline & At least one member suffers from hunger during last year & 0.296 & 0.113 \\
\hline & Health Dimension & & 0.257 \\
\hline \multirow{4}{*}{ 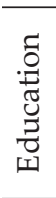 } & No one has completed five years of schooling & 0.226 & 0.115 \\
\hline & At least one school-age child not enrolled in school & 0.077 & 0.039 \\
\hline & No one has financial literacy & 0.228 & 0.116 \\
\hline & Education Dimension & & 0.27 \\
\hline \multirow{6}{*}{ 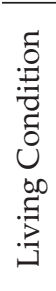 } & No electric connection at the residence & 0.262 & 0.080 \\
\hline & No access to safe drinking water & 0.183 & 0.056 \\
\hline & No access to improved sanitation & 0.457 & 0.140 \\
\hline & Cooks using dung, wood or charcoal, crop residue as fuel. & 0.461 & 0.141 \\
\hline & Household owns at most one census asset & 0.183 & 0.056 \\
\hline & Living Condition Dimension & & 0.473 \\
\hline
\end{tabular}

Source: Authors' computation based on household survey 2018.

castes. $52 \%(47 \%)$ of the scheduled castes (general castes) households are multi-dimensionally poor. Moreover, contribution of the households belonging to scheduled castes to the district MPI is 36\% which is highest among the contribution of the social castes to the overall MPI. The contribution of scheduled castes and contribution of the scheduled tribes are greater than their population share whereas the contribution of general castes and contribution of the OBCs are lesser than their population share.
It concludes that distribution of multidimensional poverty is skewed towards lower social castes in Purulia district. The combined contribution of the lower social castes is $61 \%$ and they account for $55 \%$ of the total sample size.

Table 6 shows the contribution of the individual indicators and the dimensions to overall poverty in Purulia districts. Among the twelve indicators the deprivation of improved cooking fuel and 
Table 7: Extent of Multidimensional Poverty among the Sample Households (N=698)

\begin{tabular}{cc}
\hline Level of Multidimensional Poverty & Households of Purulia District \\
\hline Destitution $(1 \geq$ WDS $>0.7)$ & $08(1.14)$ \\
Severe $(1 \geq W D S \geq 0.5$ & $67(9.6)$ \\
Marginal $(0.5>W D S \geq 0.33$ & $276(39.54)$ \\
Vulnerable $(0.33>$ WDS $\geq 0.20$ & $177(25.36)$ \\
Non-poor $(0.2>$ WDS $\geq 0$ & $178(25.50)$ \\
\hline Total & $\mathbf{6 9 8}(\mathbf{1 0 0})$ \\
\hline
\end{tabular}

Source: Authors' computation based on household survey 2018.

deprivation of improved sanitation are to leading contributors to poverty. Each of them contributes $14 \%$ to overall poverty. The indicators of unexpected mortality, deprivation in school enrolment, deprivation in access to formal health facility (contribution are less than 5\%) are the least contributors to overall poverty. Note that each of the indicators of asset poverty and unsafe source of drinking water account for $5.6 \%$ of the overall poverty. It is worth nothing that the dimension of living condition has highest contribution $(47.3 \%)$ to poverty followed by education and health dimensions.

In order to reduce the influence of the cut-off values on the identification of multidimensional poor we study the extent of multidimensional poverty instead of the incidence of poverty. We have categorized the households into five hierarchical categories with respect to the sum of weighted score of the selected indicators as shown in table-7. We find that $10 \%$ of the sample households are severely poor. Among the severely poor $12 \%$ households are destitute who account $1.14 \%$ of the total households in our sample. $39 \%$ of the households in Purulia district are marginally poor. Hence, almost half of the sample households are multi-dimensionally poor. It is evident that $25 \%$ of the sample households are vulnerable of multidimensional poverty. Therefore, this study explores that three fourth of the households in Purulia district are either vulnerable or poor in multiple dimensions of poverty.

\section{CONCLUSION}

This study reveals that the incidence and extent of multidimensional poverty in the district of Purulia is higher than that in national level. But the breadth of poverty is almost equal to that in India as a whole. In respect of the incidence and intensity of multidimensional poverty there is a wide variation across the social castes. Among the social castes tribals are the poorest preceded by scheduled castes, general castes and OBCs. Among the indicators, not having improved sanitation and use of dirty fuel for cooking both have highest contribution to the district MPI. Therefore, the district of Purulia has to travel a long way to eradicate multidimensional poverty achieving Sustainable Development Goals (SDGs). The descriptive statistics confirms that SHG centric microfinance, total sanitation program, LPG extension programme and financial inclusion programmes are not functioning wisely in the district of Purulia. Therefore, we may suggest taking more intensive programs for generation of off-farm occupation like tourism, small scale/cottage industrial development like pottery, lakh culture, sericulture etc. through group centric microfinance and financial inclusion schemes which have great prospect in Purulia district. These programs help to increase income of the households, consciousness regarding standard of living for reducing the extent of multidimensional poverty. The government has to take further extension of the programmes like sanitation, LPG connections, rationing systems etc. to enhance the living conditions of the poor.

\section{REFERENCES}

Alkire, S. and Foster, J.E. 2007. Counting and Multidimensional Poverty Measures. OPHI Working Paper 7, Oxford University. http//ophi.qeh.ox.ac.uk Assessed 2 May, 2015

Alkire, S. and Foster, J.E. 2011. Counting and Multidimensional Poverty Measurement. Journal of Public Economics, 95(7-8): 476-487.

Alkire, S. and Jahan, S. 2018. The New Global MPI 2018: Aligning with the Sustainable Development Goals, UNDP Human Development Report Office (HDRO) Occasional Paper, United Nations Development Programme (UNDP).

Alkire, S. and Santos, M.E. 2010. Acute Multidimensional Poverty: A New Index for Developing Countries. Oxford Poverty and Human Development Initiative, Working 
Paper No. 38, Oxford Department of International Development, University of Oxford. http//ophi.qeh.ox.ac. uk Assessed 2 May, 2015

Alkire, S., Roche, J.M., Santos, M.E. and Seth, S. 2011. Multidimensional Poverty Index 2011: Brief Methodological Note. Oxford Poverty and Human Development Initiative, available at http//www.ophi.org. uk Assessed 25 June, 2015

Alkire, S. and Robles, G. 2017. Global Multidimensional Poverty Index 2017, Briefing 47, OPHI, http// www.ophi. org.uk Accessed 20 July, 2018.

Bagli, S. 2015. Multidimensional Poverty: An Empirical Study in Bankura District, West Bengal. Journal of Rural Development, 34(3): 327-342.

De, S. and Datta, K. 2014. Multidimensional poverty index of totos- The smallest and primitive tribe in Jalpaiguri district of West Bengal. Economic Affairs, 59(4): 605-611.

Dehury, B. and Mohanty, K.S. 2015. Regional Estimates of Multidimensional Poverty in India. Discussion Paper No. 2015-34 May 06, 2015.http//www.economics-ejournal.org/ economics/journalarticles/2015-36 Accessed 10 December, 2018

Haveman, R. and Dhongde, S. 2014. Multi- Dimensional Poverty Index: An Application to the United States. http:// ssrn.com/abstract=2588584 Assessed on 22 March, 2017
Ningaye, P., Ndjanyou, L. and Guy Marcel Saakou. 2011. Multidimensional Poverty in Cameroon: Determinants and Spatial Distribution. AERC Research Paper, African Economic Research Consortium, Nairobi. Kenya.

Roy, P., Ray, S. and Haldar, S.K. 2018. Socio-economic Determinants of Multidimensional Poverty in Rural West Bengal: A Household Level Analysis. Journal of Quantitative Economics. https://doi.org/10.1007/s40953018-0137-4 Assessed 28 March, 2019.

Ruggeri Laderchi, C., Saith, R. and Stewart, F. 2003. Does it Matter that we do not Agree on the Definition of Poverty? A Comparison of Four Approaches. Oxford Development Studies, 31(3): 243-274.

UNDP. 2018. Human Development Report, 2018. Palgrave Macmillan, New York.

Vijaya, R., Lahoti, R. and Swaminathan, H. 2014. Moving from the Household to the Individual: Multidimensional Poverty Analysis. World Development, 59(2): 70-81.

Zahra, K. and Zafar, T. 2015. Marginality as a Root Cause of Urban Poverty: A Case Study of Punjab. The Pakistan Development Review, 54(4): 629-650. 
